\title{
Yeast Morphology Assessment through Automated Image Analysis during Fermentation
}

\author{
Mario Guadalupe-Daqui, Mandi Chen, Katherine A. Thompson-Witrick (D) and Andrew J. MacIntosh * \\ Food Science and Human Nutrition Department, University of Florida, Gainesville, FL 32611, USA; \\ mguadalupe@ufl.edu (M.G.-D.); mandi.chen@ufl.edu (M.C.); kthompsonwitrick@ufl.edu (K.A.T.-W.) \\ * Correspondence: andrewmacintosh@ufl.edu; Tel.: +1-352-294-3594
}

Citation: Guadalupe-Daqui, M.; Chen, M.; Thompson-Witrick, K.A.; MacIntosh, A.J. Yeast Morphology Assessment through Automated Image Analysis during Fermentation. Fermentation 2021, 7, 44. https:// doi.org/10.3390/fermentation 7020044

Academic Editor: Claudia Gonzalez Viejo

Received: 5 March 2021

Accepted: 20 March 2021

Published: 24 March 2021

Publisher's Note: MDPI stays neutral with regard to jurisdictional claims in published maps and institutional affiliations.

Copyright: (c) 2021 by the authors. Licensee MDPI, Basel, Switzerland. This article is an open access article distributed under the terms and conditions of the Creative Commons Attribution (CC BY) license (https:/ / creativecommons.org/licenses/by/ $4.0 /)$.

\begin{abstract}
The kinetics and success of an industrial fermentation are dependent upon the health of the microorganism(s) responsible. Saccharomyces sp. are the most commonly used organisms in food and beverage production; consequently, many metrics of yeast health and stress have been previously correlated with morphological changes to fermentations kinetics. Many researchers and industries use machine vision to count yeast and assess health through dyes and image analysis. This study assessed known physical differences through automated image analysis taken throughout ongoing high stress fermentations at various temperatures $\left(30^{\circ} \mathrm{C}\right.$ and $\left.35^{\circ} \mathrm{C}\right)$. Measured parameters included sugar consumption rate, number of yeast cells in suspension, yeast cross-sectional area, and vacuole cross-sectional area. The cell morphological properties were analyzed automatically using ImageJ software and validated using manual assessment. It was found that there were significant changes in cell area and ratio of vacuole to cell area over the fermentation. These changes were temperature dependent. The changes in morphology have implications for rates of cellular reactions and efficiency within industrial fermentation processes. The use of automated image analysis to quantify these parameters is possible using currently available systems and will provide additional tools to enhance our understanding of the fermentation process.
\end{abstract}

Keywords: yeast morphology; automated image analysis; heat stress; vacuoles; cell size; computer vision

\section{Introduction}

The fermentative properties of yeast have been utilized for thousands of years in a spectrum of applications including brewing, baking, biofuels, etc. For an optimal performance in most applications, the health of the yeast should be maintained throughout the fermentation [1]. Yeast health is typically measured through the determination of viability and vitality via metabolic dyes, however, there are other known morphological characteristics that have been shown to be indicators of yeast health [2,3] including size, number and shape of organelles (i.e., vacuoles). To optimize the fermentation process and quickly respond to deviations, data collection concerning yeast condition should be rapid and include automation as to be completed in a timely manner. If implemented, automated assessment can also provide supplemental information including details of fermentation rate per suspended cell which may assist both researchers and industry to better understand the fermentative process. This study used an open-source image processing to track changes in yeast morphology through an automated analysis of various characteristics during high-stress fermentations.

Commonly measured morphological characteristics of yeast include cell size (commonly expressed as cross-sectional area or volume) and the number of buds. These characteristics are used to evaluate yeast cells under a wide variety of environmental stress sources, for example, yeast cell size measurements have been used by various researchers $[2,4]$ as an indicator of the effects of stressors such as temperature and ethanol. 
Additionally, cell size and the number of budding vs. single cells were successfully used to assess the effects of hyperbaric stress and various gas compositions on yeast physiological state [5]. The vacuolar structure (size and shape) and number are other yeast morphological characteristics commonly assessed. Yeast vacuoles are dynamic organelles with a changing morphology during fermentation as a response to different stress sources [6-8]. These researchers studied yeast vacuole formation under osmotic and ethanol stress environments during fermentation at low temperatures. Both studies concluded that under high osmotic environments, each cell contained at least two or more yeast vacuoles which presented a fragmented (small diameter) structure. These studies also reported that yeast vacuoles formed under high ethanol concentrations were less fragmented and were described as single swollen vacuoles that occupied almost the entire cytoplasm. Furthermore, deficiencies of this organelle in yeast (observable under the microscope) have been linked to cell death [9] and the cessation of fermentation. A better understanding of yeast performance during fermentation can be attained by combining measurements of fermentation kinetics with morphological characteristics of the cell. Tibayrenc et al. [2] studied the evolution of Saccharomyces cerevisiae morphology under different stressors to infer cell viability. In summary, there have been numerous studies that effectively relate yeast morphological characteristics such as cell size, length, or state, to yeast properties during fermentation $[2,10,11]$.

The automated analysis of images facilitates the examination of microorganisms at specific times throughout a process, providing instantaneous information concerning the parameters assessed. Typically, automated image analysis is divided into three stages: image processing, variable acquisition and statistical analysis [12]. Automated analysis of yeast cell images is not a novel concept and is most commonly used to assess the number of cells suspended within media. There are existing software and devices such as the Cellometer developed by Nexcelom Bioscience LLC (Lawrence, MA, USA) that can process yeast images and assess the number of cells and viability. CalMorph v1.3 is software created to analyze yeast cells delivering information regarding cell morphology, phase, etc. However, this software is limited to microscopic images that have been fluorescence stained [13]. There are numerous examples of researchers independently using various software programs to assess images of yeast for specific properties. For example, the software Matlab v.6.1 was used by Coelho et al. [5] to fully automate the image processing procedure from an image obtained using an optical microscope. These researchers studied the effects of hyperbaric stress on single and budding yeast cells using cell area size, major and minor axis length measured through Matlab. The open-source software ImageJ has been used as an image processing software by numerous researchers $[14,15]$ to assess properties of various microorganisms. Stolze et al. [16] developed an automated counting method for Petrifilm plates using ImageJ, reducing the time of analysis significantly.

This study aimed to combine the use of automated image analysis with a modern understanding of how yeast morphology changes in response to adverse environmental conditions. This helped to correlate how changes in the morphological state of yeast influenced the process attributes throughout the fermentation. Specifically, fermentations were conducted at extreme temperature conditions $\left(30^{\circ} \mathrm{C}\right.$ and $\left.35^{\circ} \mathrm{C}\right)$ where morphological changes were expected based upon previous work. Throughout the fermentation, hundreds of images were collected and attributes such as cell cross-sectional area and vacuole size were quantified through automated analysis. These were then correlated with fermentation kinetics to enhance understanding of the changes undergone by the yeast, and the effect upon the entire fermentation. The techniques used in this paper can easily be applied in the fermentation industries where automated data collection of this nature is often already taking place allowing rapid assessment of yeast adaptions to different stress sources. 


\section{Materials and Methods}

\subsection{Media and Yeast}

The media used in this research was based upon a rum fermentation and was composed of $75 \% w / w$ distilled water, $18.5 \% w / w$ sugar cane, and $6.5 \% w / w$ blackstrap molasses. This broth was supplemented with $0.8 \% w / w$ yeast extract to increase the amount of free amino nitrogen to $320 \mathrm{mg} / \mathrm{L}$ (measured via Ninhydrin method as described in the American Society of Brewing Chemists (ASBC) Wort-12 method [17]). All the ingredients were dissolved at $50{ }^{\circ} \mathrm{C}$ and sterilized at $121^{\circ} \mathrm{C}$ for $15 \mathrm{~min}$. This media had a sugar concentration of $24 \% w / w$ and was used for both the propagation and fermentation processes. However, in the first propagation, the media was diluted to $15 \% w / w$ using deionized water. A Saccharomyces cerevisiae strain provided by Lallemand (DISTILAMAX ${ }^{\circledR}$ SR-Montreal, QC, Canada) was utilized throughout the experiments based upon recommendations from the supplier concerning survivability under adverse conditions and the ability to ferment sugars found in the raw materials used. The active dry yeast (ADY) was stored between $1{ }^{\circ} \mathrm{C}$ and $4{ }^{\circ} \mathrm{C}$ prior to its rehydration and propagation.

\subsection{Rehydration and Propagation}

For each experiment, $10 \mathrm{~g}$ of ADY were rehydrated using $100 \mathrm{~mL}$ of sterile tap water at $35{ }^{\circ} \mathrm{C}$ for $15 \mathrm{~min}$. Rehydrated yeast was propagated in a two-step process to achieve a consistent inoculum and sufficient biomass to pitch the $4 \mathrm{~L}$ fermentors. The first propagation was performed using $150 \mathrm{~mL}$ of media (diluted to $15 \% \mathrm{w} / \mathrm{w}$ ), while the second propagation was performed using $350 \mathrm{~mL}$ of media at $(24 \% \mathrm{w} / \mathrm{w})$. Both propagation steps were pitched at $30 \times 10^{6}$ viable yeast cells $/ \mathrm{mL}$ and run for $24 \mathrm{~h}$ at $35^{\circ} \mathrm{C}$ each as per recommendations from the supplier.

\subsection{Fermentation}

Each fermentation run started under identical conditions, using the same media, and pitched with the same yeast to assess the differences throughout the process by changing only the temperature. Fermentors (total volume of $\sim 5 \mathrm{~L}$ ) were filled with $4 \mathrm{~L}$ of media $(24 \%$ $w / w)$, oxygenated for two minutes, and pitched with $30 \times 10^{6}$ viable yeast cells $/ \mathrm{mL}$. Two temperatures were selected to complete the fermentation processes, $30^{\circ} \mathrm{C}$ (low temperature) and $35^{\circ} \mathrm{C}$ (high temperature). Each experiment was performed by duplicate. Samples were taken at intervals between 6 to $12 \mathrm{~h}$ in an attempt to monitor the reductions in the sugar concentration every 3-4\% $w / w$, approximately, during peak fermentation. The volume of each sample was $125 \mathrm{~mL}$ and was divided into smaller aliquots to assess the fermentation attributes and the yeast morphology.

\subsection{Measurement of Sugar Concentration and Viable Cells in Suspension}

To measure the sugar concentration throughout the fermentation, $30 \mathrm{~mL}$ of sample were degassed, centrifuged and filtered. These samples were analyzed using an Anton Paar Alex 500 (Graz, Austria), which measured the density of the sample through an oscillating U-tube glass. The density measured was then used to calculate the real sugar concentration and expressed in $\% w / w$, or ${ }^{\circ} \mathrm{P}$ (analogous to percent sugar by weight). Cells in suspension were measured during the fermentation process using a hemocytometer and a microscope with $400 \times$ magnification, as described in the ASBC Yeast-4 method [18]. Viable cells were identified and counted using the methylene blue technique described by Painting and Kirsop [19]. The number of viable cells in suspension at each sample point was calculated by multiplying the percent of viable cells by the total number of cells in suspension. 


\subsection{Models}

The sugar concentration was modeled using the logistic model described in Yeast14 [20] method and shown in Equation (1).

$$
P_{(t)}=P_{e}+\frac{P_{i}-P_{e}}{1+\exp p^{(-B(t-M))}}
$$

where $\mathrm{P}_{(\mathrm{t})}$ is a function that represents the sugar concentration at a specific time $\mathrm{t}(\% w / w)$, $\mathrm{P}_{\mathrm{i}}$ is the upper asymptote of the curve $(\% w / w), \mathrm{P}_{\mathrm{e}}$ is the lower asymptote of the curve $(\% w / w), \mathrm{M}$ is the time of the inflection point of the curve (h), and B is the slope of the curve $\left(\% \mathrm{w} /\left(\mathrm{w}^{*} \mathrm{~h}\right)\right)$. To determine the consumption rate of the sugar during the fermentation, the first derivative of the logistic model (Equation (1)) was taken with respect to time (Equation (2)) as follows:

$$
\frac{\partial}{\partial t}\left(P_{e}+\frac{P_{i}-P_{e}}{1+\exp (-B *(t-M))}\right)=\left(\frac{B\left(P_{i}-P_{e}\right) \exp ^{-B(x-M)}}{\left(\exp ^{-B(x-M)}+1\right)^{2}}\right)
$$

The cells in suspension data were modeled using the step model (Equation (3)) as described by Rudolph et al. [21]. This model was utilized due the amplitude and the Heaviside step function that describe the maximum number of cells in suspension during the fermentation and the final number of cells at the end of the process, respectively.

$$
Y_{(t)}=A\left(\frac{\exp ^{-\frac{1}{2}\left(\frac{\frac{t-\mu}{\sigma}}{1+\left(H_{t} * S\right)}\right)^{2}}}{1+\left(H_{t} * S\right)}\right)+\left(A-\frac{A}{(1+S)}\right) * H_{(t)}
$$

$\mathrm{Y}_{(\mathrm{t})}$ is a function that represents the number of cells in suspension at a specific time $\mathrm{t}$ (cells $/ \mathrm{mL}$ ), A is the amplitude (cells $/ \mathrm{mL}$ ), $\mathrm{m}$ is the midpoint (h), $\sigma$ is the width factor (h), $\mathrm{S}$ modifies the height of the step in this function (unitless), and $\mathrm{H}_{(\mathrm{t})}$ is the Heaviside step function.

\subsection{Image Collection}

Prior to the image collection, yeast cells were centrifuged and washed three times using deionized water and stained with a $0.01 \% w / v$ methylene blue solution to differentiate living and death cells at each data point. Various images were taken from each experiment such that approximately 80 to 360 cells were captured at each sampling point. Images were captured using a Nikon Eclipse Ci-L microscope at $1000 \times$ magnification, combining a $100 \times$ oil immersion objective and a $10 \times$ eyepiece.

\subsection{Manual Analysis of Vacuole Count}

The manual analysis of the cell images was completed using the Nikon NIS-Elements software V5.30.01 compatible with the microscope. The cross-sectional area (CSA) of yeast and vacuoles were measured individually using an auto selection tool in conjunction with a five-point ellipse and a freehand selection tool. Once the areas were selected, the software converted the pixels into a measurement of surface area based upon previous calibrations. Budding yeast cells were assessed as two separate cells, dividing them at the cleavage. Vacuoles were clearly identifiable due to the difference in shade compared to the rest of the cell (Figure 1). The light settings on the microscope were adjusted at the beginning of the experiment to maximize this contrast. The data collected were exported and saved as an excel file for further calculations to determine the average yeast CSA and the ratio between vacuole and yeast CSA. Figure $1 \mathrm{~b}$ shows an image analyzed manually and includes all the measurements taken using this software. There were 80-360 yeast cells assessed from images at the beginning, middle, and end of each fermentation process using this method 
to validate the automated image analysis method. Yeast cells that were partially in the image were not selected for data collection using this method.

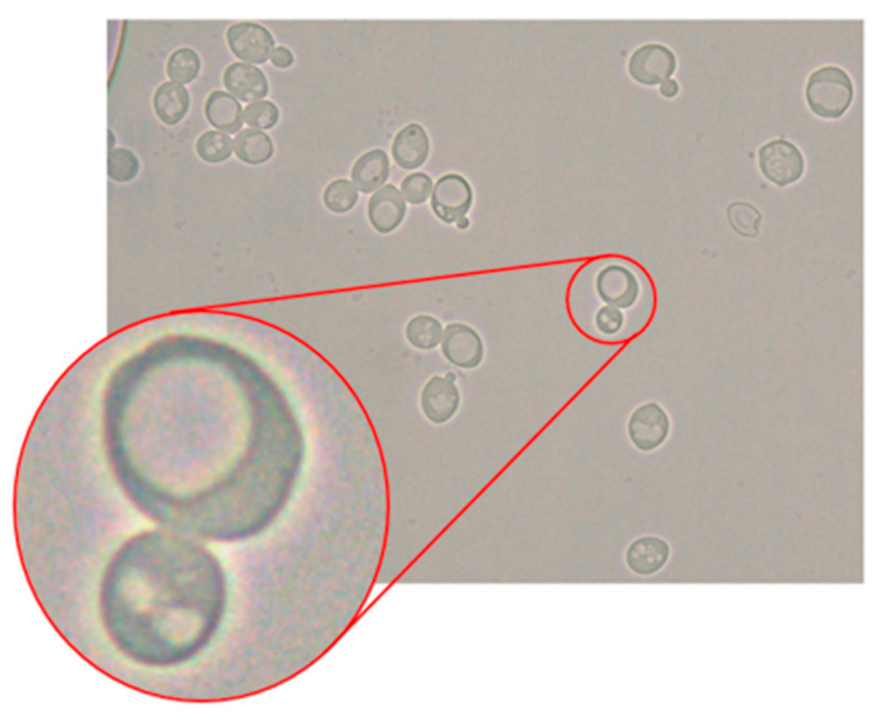

(a)

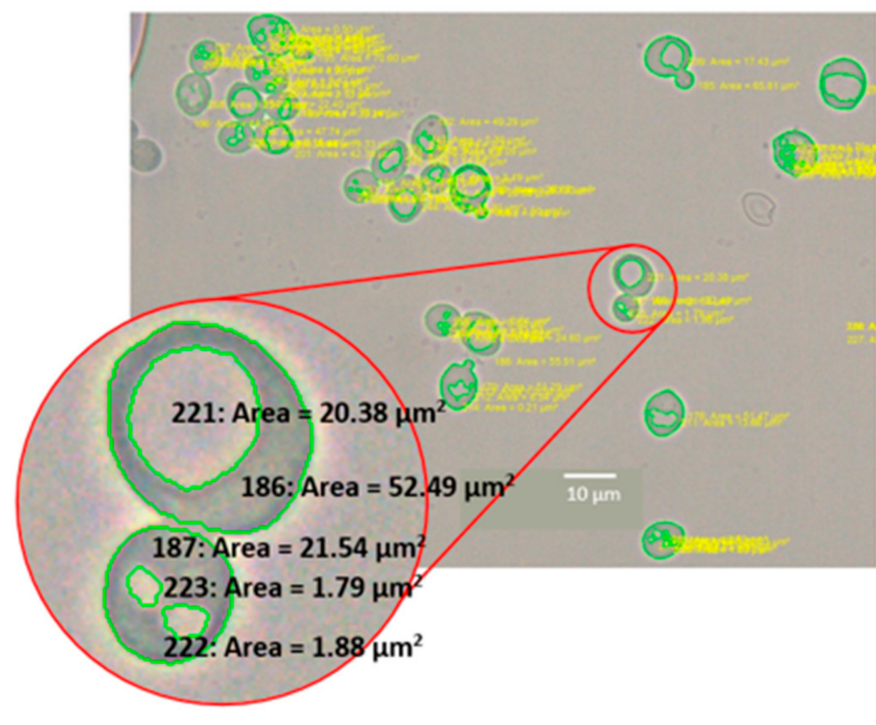

(b)

Figure 1. (a) Microscope image of yeast during fermentation $(1000 \times$ ) with enlarged budding cell (counted as two individual yeast cells) to show shading difference between vacuole and yeast cell in a raw image; (b) The same image after manual analysis of cell and vacuole cross-sectional area (CSA).

\subsection{Automated Image Analysis of Yeast and Vacuole Cross-Sectional Area}

The images of yeast taken throughout each fermentation were analyzed using ImageJ v1.8.0 software. A sample image is shown in Figure 2a. This analysis included the measurement of yeast cell CSA, total yeast CSA and total vacuole CSA. The automated image analysis was calibrated using a scale that correlated the image pixels with the scientific units of micrometers. The outline of yeast cells and the vacuoles were enhanced using tools sequentially: "binary mask", "despeckle filter", "dilation", and "pixel outlier removal". The goals of these tools were to reduce image noise that could affect the results and to enhance the distinguishing features of yeast cells from the background and the vacuoles. The binary mask converted the 32-bit image to 8-bit, which results in a black and white separation of the yeast cells (black), vacuoles (white) and background (white). The despeckle filter applied was a median filter that replaced every pixel with the median value of a $3 \times 3$ pixel region, and it removed sparsely occurring black pixels [22]. Then, the dilation tool was used to separate any yeast cells that may be touching each other due to proximity or budding. Finally, after dilation, the pixel outlier tool was applied to remove black particles with a radius of 4 pixels $(0.363 \mu \mathrm{m})$ or less. A sample of the resulting processed images is shown in Figure $2 b$. These images were then automatically assessed with an analyze particles tool that selected for analysis, objects with an area of $10-100 \mu \mathrm{m}^{2}$ and a circularity of $0.30-1.00$ (ideally, this would encompass all yeast cells). This tool enumerated and collected the cross-sectional area of all individual selected objects (Figure 2c). To measure the vacuolar cross-sectional area, everything outside of the selected objects was removed, then the image was inverted to change the black background to white and white vacuoles to black, resulting in Figure $2 \mathrm{~d}$. Yeast cells and the vacuoles that were partially in the image were not included in the analysis by the software. The data collected were exported and saved as an excel file for subsequent calculation of the average yeast cell cross-sectional area and the ratio between vacuole and cell cross-sectional area. The automated analysis of the cell images was completed after the fermentation processes. 


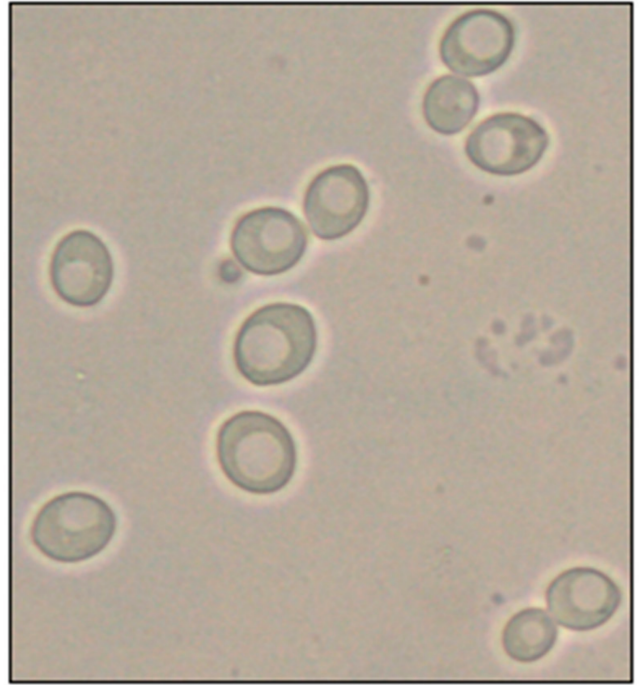

(a)

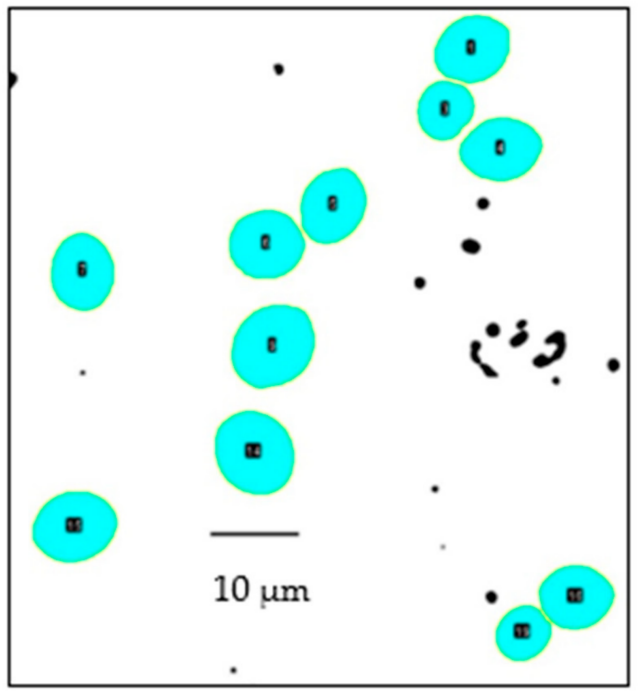

(c)

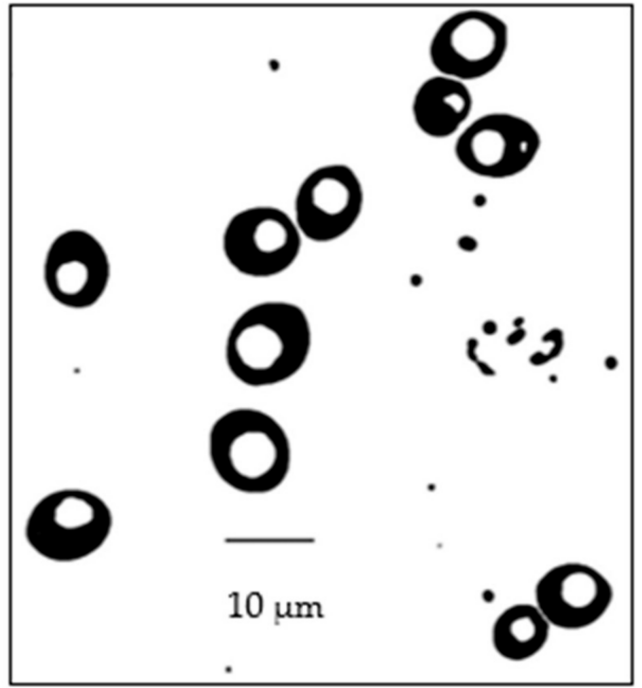

(b)

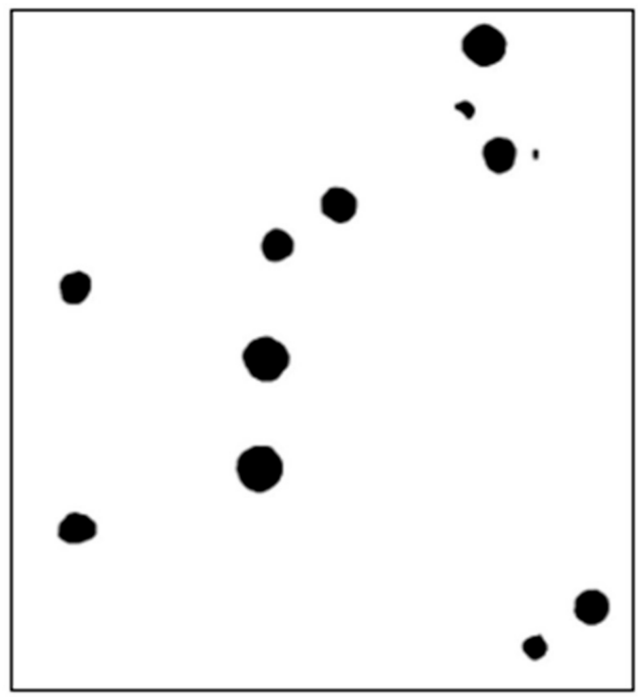

(d)

Figure 2. (a) Microscopic image of yeast cells (1000 $\times$ magnification) at $6.5 \mathrm{~h}$ before processing; (b) After image processing; (c) After yeast cell area data were collected and region of interest established; (d) After clearing outside region of interest and inverting image and vacuolar area data was collected.

\subsection{Statistical Analysis}

In this study, Minitab 19 was used to determine significant differences $(p<0.05)$ among the yeast CSA and CSA ratio between vacuoles and yeast cells throughout each fermentation and between fermentations at $30^{\circ} \mathrm{C}$ and $35^{\circ} \mathrm{C}$. The validation of the automated image analysis method was performed by calculating the percentage error between the results obtained manually using the Nikon software V5.30.01 and automatically using ImageJ.

\section{Results}

\subsection{Fermentation Kinetics}

The sugar consumption model (Equation (1)) and the model for number of cells in suspension (Equation (3)) were fit to the data from each fermentation. The best fit model parameters for the combined fermentation data at each temperature are presented in Table 1 . The sugar concentration regression resulted in high $\mathrm{r}^{2}$ values of 0.99 , while the 
slightly more variable cell in suspension data resulted in values of 0.91 and 0.85 for 30 and $35^{\circ} \mathrm{C}$, respectively.

Table 1. Step and logistic model parameters.

\begin{tabular}{|c|c|c|c|c|c|c|c|}
\hline \multirow[b]{2}{*}{ Attribute } & \multirow[b]{2}{*}{ Experiment } & \multicolumn{6}{|c|}{ Parameters } \\
\hline & & Model & $\underset{\text { (Cells/mL) }}{\mathrm{A}}$ & $\begin{array}{l}\mu \\
h\end{array}$ & $\begin{array}{l}\sigma \\
h\end{array}$ & $\begin{array}{c}\text { S } \\
\text { Unitless }\end{array}$ & Model Fit $\mathbf{r}^{2}$ \\
\hline \multirow{3}{*}{$\begin{array}{c}\text { Cells in } \\
\text { suspension }\end{array}$} & $30{ }^{\circ} \mathrm{C}$ & Step model & 168.24 & 20.65 & 13.77 & 0.00 & 0.91 \\
\hline & $35^{\circ} \mathrm{C}$ & Step model & 79.72 & 13.25 & 11.38 & 0.05 & 0.89 \\
\hline & & & $\begin{array}{c}\mathrm{Pi} \\
\% w / w\end{array}$ & $\begin{array}{c}\mathrm{Pe} \\
\% w / w\end{array}$ & $\begin{array}{c}\text { B } \\
\% w /\left(w^{*} h\right)\end{array}$ & $\begin{array}{c}\mathbf{M} \\
\mathbf{h}\end{array}$ & Model Fit $r^{2}$ \\
\hline Sugar & $30^{\circ} \mathrm{C}$ & Sigmoidal 4P & 29.92 & 3.14 & -0.12 & 11.08 & 0.99 \\
\hline consumption & $35^{\circ} \mathrm{C}$ & Sigmoidal $4 \mathrm{P}$ & 26.93 & 10.00 & -0.14 & 11.39 & 0.99 \\
\hline
\end{tabular}

Fermentations at $35^{\circ} \mathrm{C}$ and $30^{\circ} \mathrm{C}$ both showed a typical sigmoidal sugar consumption curve (Figure 3). The times of maximum fermentation rate (parameter $\mathrm{M}$ ) were similar in both, at $30^{\circ} \mathrm{C}(11.08 \mathrm{~h})$ and $35^{\circ} \mathrm{C}(11.39 \mathrm{~h})$. At $30^{\circ} \mathrm{C}$, yeast metabolized more total sugars $(20.8 \% w / w)$ compared to $35^{\circ} \mathrm{C}(13.9 \% w / w)$. During fermentations at both temperatures, the number of viable cells in suspension increased (Figure 4). However, the maximum number of cells in suspension during the $35^{\circ} \mathrm{C}$ fermentations was approximately $50 \%$ fewer compared to the $30^{\circ} \mathrm{C}$ fermentations. These results are in accordance with the results previously reported by Torija et al. [23] and Reddy and Reddy [24] who used Saccharomyces cerevisiae strains to study the influence of temperature on the number of cells and the fermentation rate. Both studies found that at $35^{\circ} \mathrm{C}$, the cells in suspension were reduced approximately $50 \%$ compared to $30^{\circ} \mathrm{C}$. Similarly, they found a higher final attenuation level when fermenting at $35^{\circ} \mathrm{C}$ compared to $30^{\circ} \mathrm{C}$. Torrija et al. [23] reported a drop in the ethanol yield of $11 \%$ approximately when fermenting at $35^{\circ} \mathrm{C}$. This low yield of ethanol was almost certainty linked to the reduced consumption of substrate.

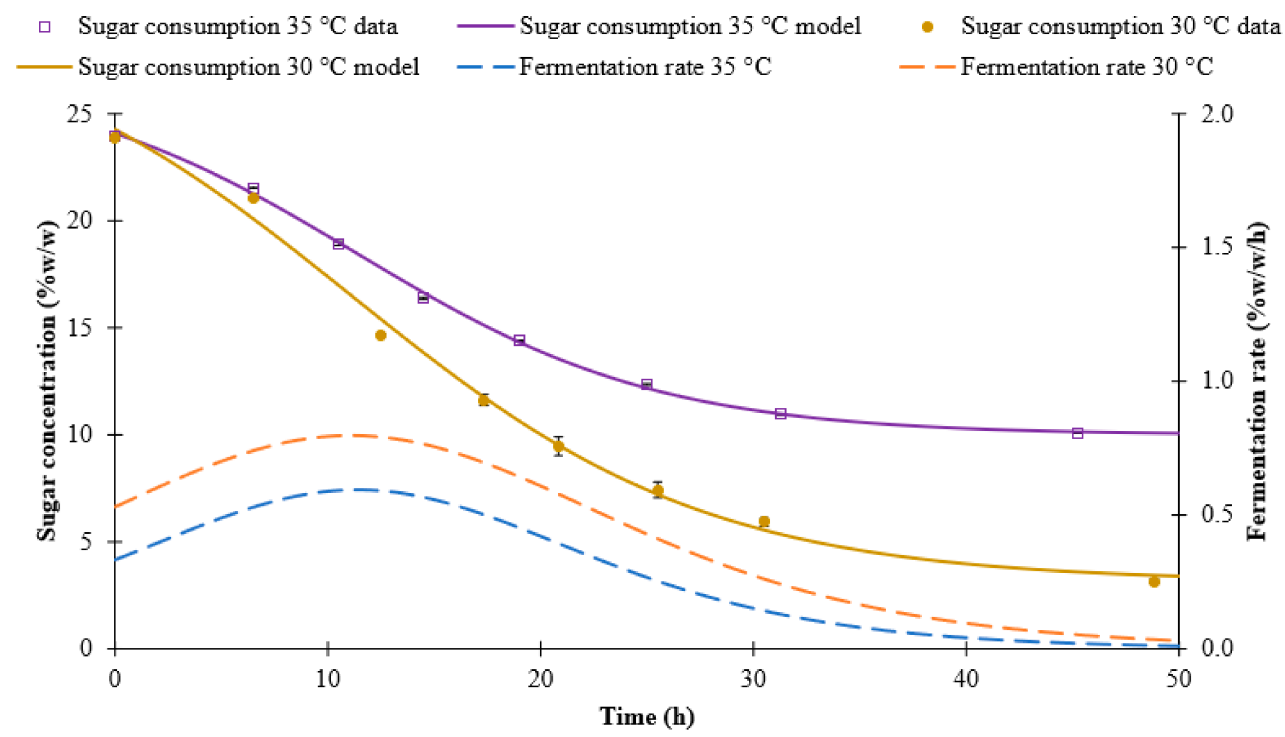

Figure 3. Sugar concentration and fermentation rate calculated by taking the 1st derivative of the sugar consumption model (Equation (2) and Equation (1), respectively). Data shown represent fermentation data at $30^{\circ} \mathrm{C}$ (brown circles) and $35^{\circ} \mathrm{C}$ (purple squares); sugar consumption model at $30^{\circ} \mathrm{C}$ (purple line) and $35^{\circ} \mathrm{C}$ (brown line); and fermentation rate model at $30^{\circ} \mathrm{C}$ (orange dashed line) and $35^{\circ} \mathrm{C}$ (blue dashed line). Fermentations were performed in duplicate. The error bars represent the standard deviation of the data. 


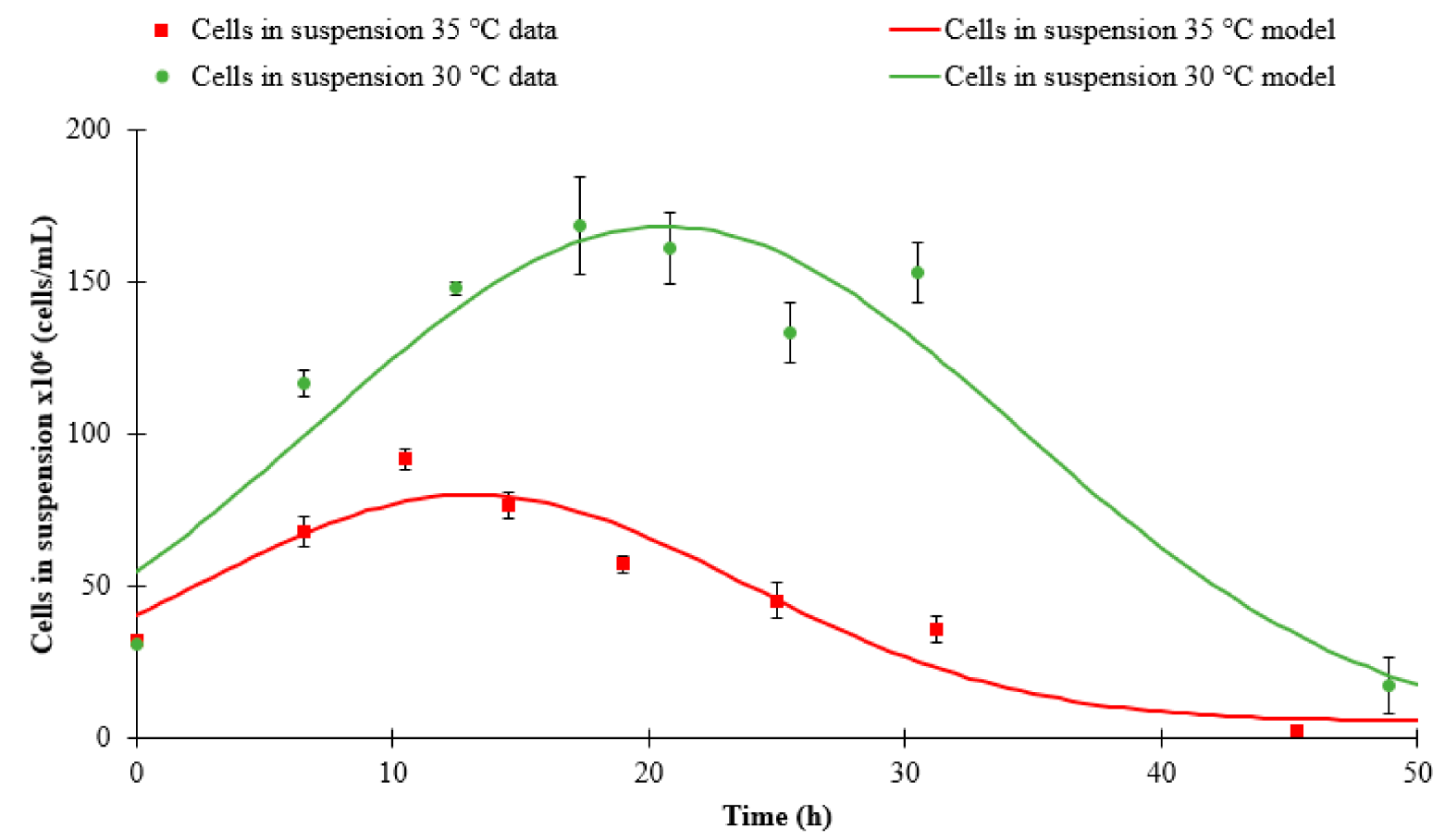

Figure 4. Viable cells in suspension throughout the fermentation. Data shown represent fermentation data at $30{ }^{\circ} \mathrm{C}$ (green circles) and $35{ }^{\circ} \mathrm{C}$ (red squares); cells in suspension model (Equation (3)) at $30^{\circ} \mathrm{C}$ (green line) and $35^{\circ} \mathrm{C}$ (red line). Fermentations were performed in duplicate. The error bars represent the standard deviation of the data.

\subsection{Manual Image Analysis}

During the fermentation at both temperatures, changes in yeast size, as well as in the size of the vacuoles present were observed. Figures 5 and 6 show images of yeast cells and a summary of the average of the yeast and vacuole CSA throughout the fermentation for $30^{\circ} \mathrm{C}$ and $35{ }^{\circ} \mathrm{C}$, respectively. These values were manually assessed from 80-360 cells per sampling time using the methods described above. Images at $30{ }^{\circ} \mathrm{C}$ show that the average yeast CSA decreased from $43.4 \mu \mathrm{m}^{2} \pm 13.6 \mu \mathrm{m}^{2}$ to $37.1 \mu \mathrm{m}^{2} \pm 11.9 \mu \mathrm{m}^{2}$, whilst at $35^{\circ} \mathrm{C}$ there was a slight increase of CSA until after the fermentation peak (approximately after $15 \mathrm{~h}$ ). Images also indicate a constant decrease in the size of vacuoles, until almost no vacuoles were present in the yeast cells towards the end of the fermentation at both temperatures. Given the large standard deviation in the size of the yeast, it was necessary to assess a large number of cells to provide statistically significant results. The manual analysis was labor-intensive, thus, substantial resources would be necessary to observe trends over the fermentation. To accomplish this goal, the automated analysis tool was developed so that many sampling times could be automatically assessed within a reasonable amount of time. Samples at the beginning, middle, and end of the fermentation processes were manually counted to validate the automated results. 


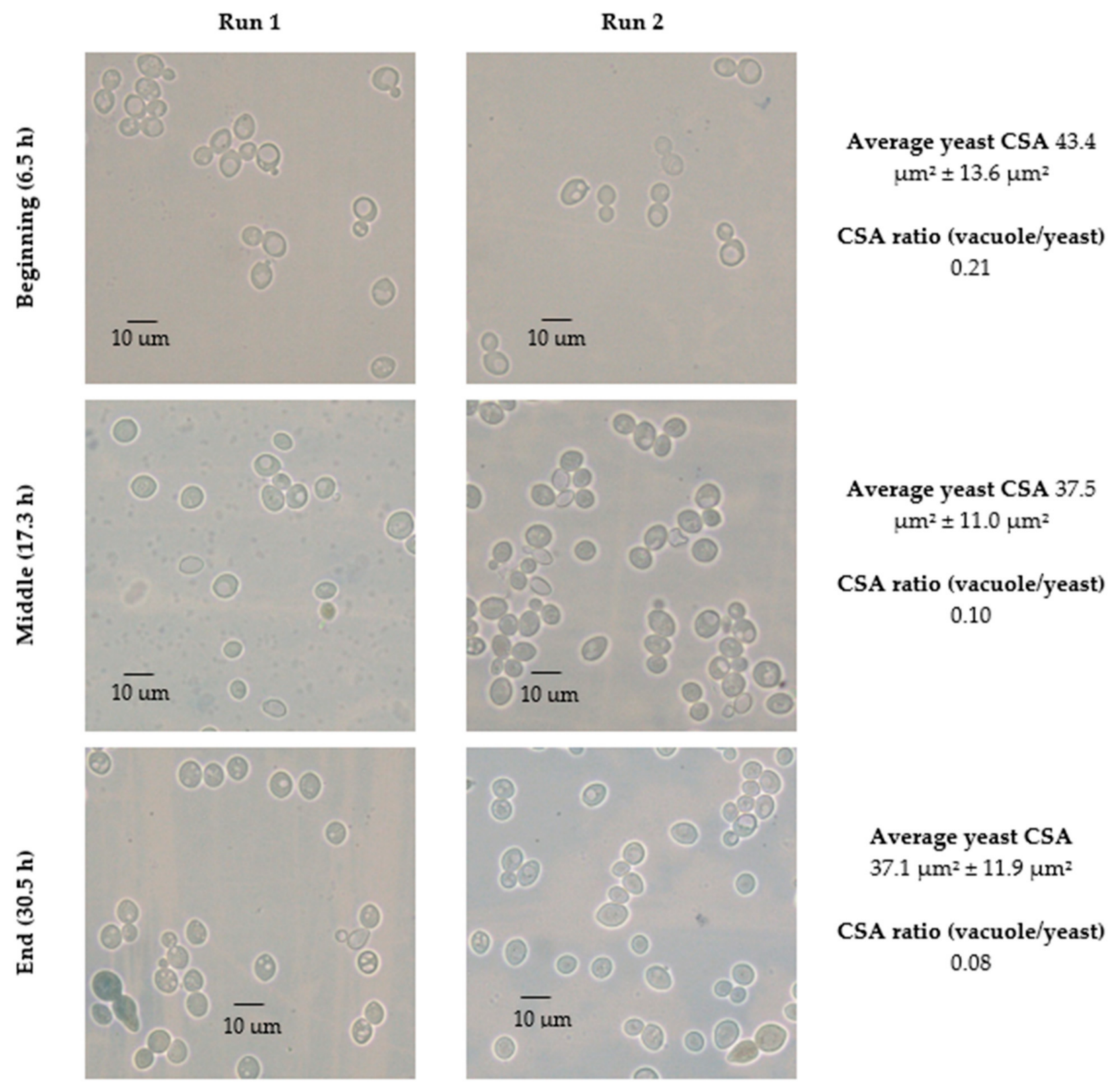

Figure 5. Bright-field microscopic image of yeast cells $(1000 \times$ magnification) of the duplicate runs from beginning, middle and end of the fermentation processes at $30^{\circ} \mathrm{C}$. The media included $0.01 \% w / v$ methylene blue solution to differentiate non-viable cells from the analysis. The yeast CSA and CSA ratio (vacuole to yeast area) were determined manually using the Nikon software. 

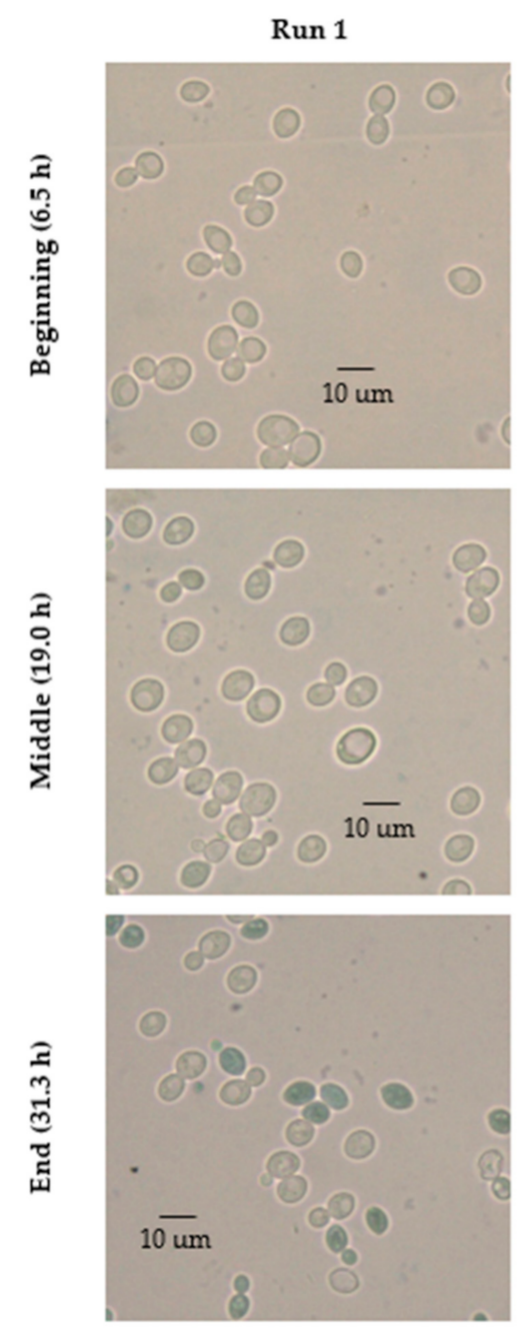

Run 2

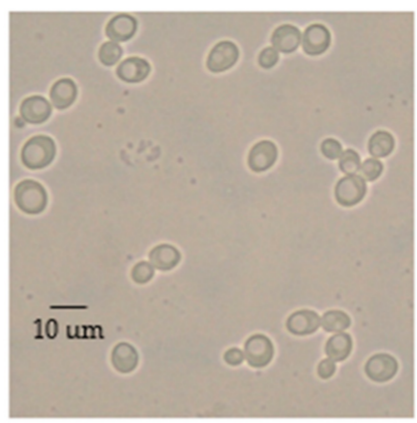

\author{
Average yeast CSA 42.6 \\ $\mu \mathrm{m}^{2} \pm 12.7 \mu \mathrm{m}^{2}$
}

CSA ratio (vacuole/yeast) 0.23

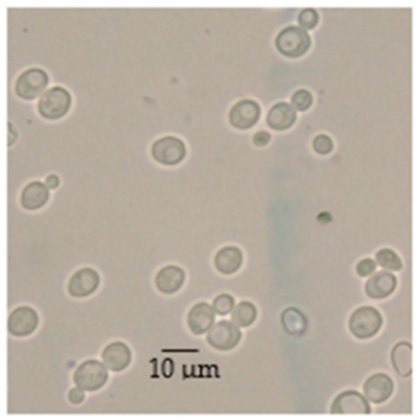

Average yeast CSA 42.8 $\mu \mathrm{m}^{2} \pm 12.0 \mu \mathrm{m}^{2}$

CSA ratio (vacuole/yeast) 0.18

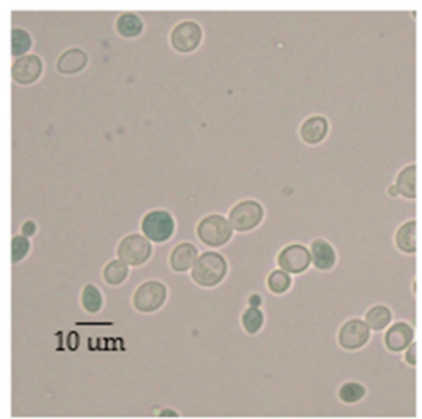

Average yeast CSA 37.0 $\mu \mathrm{m}^{2} \pm 11.4 \mu \mathrm{m}^{2}$

CSA ratio (vacuole/yeast)

0.12

Figure 6. Bright-field microscopic image of yeast cells $(1000 \times$ magnification) of the duplicate runs from beginning, middle and end of the fermentation processes at $35^{\circ} \mathrm{C}$. The media included $0.01 \%$ $w / v$ methylene blue solution to differentiate non-viable cells from the analysis. The yeast CSA and CSA ratio (vacuole to yeast area) were determined manually using the Nikon software.

\subsection{Automated Image Analysis}

For this comparison, 80-360 yeast cells were automatically analyzed at each sampling period. To assess the accuracy of the automated analysis, the results for yeast CSA, total yeast CSA, and vacuoles CSA obtained through both automated and manual image analysis are compared in Table 2. The data obtained for yeast CSA and the CSA ratio vacuole to yeast, using both the automated image analysis and the manual Nikon software, resulted in an average difference of less than $4 \%$ and $2 \%$, respectively. This shows that the data obtained in this study are reliable and comparable to the manual assessment where the Nikon software was used to measure cell morphology under the microscope. 
Table 2. Comparison of automated and manual image analysis.

\begin{tabular}{|c|c|c|c|c|c|c|c|c|c|c|c|c|c|}
\hline \multirow[b]{2}{*}{$\begin{array}{l}\text { Temp } \\
\left({ }^{\circ} \mathrm{C}\right)\end{array}$} & \multirow[b]{2}{*}{$\begin{array}{l}\text { Time } \\
\text { (h) }\end{array}$} & \multirow{2}{*}{$\begin{array}{c}\text { Manual } \\
\text { Average } \\
\text { Yeast CSA } \\
\left(\mu \mathrm{m}^{2}\right)\end{array}$} & \multirow{2}{*}{$\begin{array}{c}\text { Automated } \\
\text { Average } \\
\text { Yeast CSA } \\
\left(\mu \mathrm{m}^{2}\right)\end{array}$} & \multirow[b]{2}{*}{$\%$ Error } & \multirow[b]{2}{*}{$\begin{array}{c}\text { Average } \% \\
\text { Error }\end{array}$} & \multicolumn{3}{|c|}{ Manual } & \multicolumn{3}{|c|}{ Automated } & \multirow[b]{2}{*}{$\%$ Error } & \multirow[b]{2}{*}{$\begin{array}{c}\text { Average } \% \\
\text { Error }\end{array}$} \\
\hline & & & & & & $\begin{array}{l}\text { Total Yeast } \\
\text { CSA }\left(\mu \mathrm{m}^{2}\right)\end{array}$ & $\begin{array}{c}\text { Total } \\
\text { Vacuole } \\
\text { CSA }\left(\mu \mathrm{m}^{2}\right)\end{array}$ & $\begin{array}{l}\text { \% CSA Ratio } \\
\text { (Vacuole/Yeast) }\end{array}$ & $\begin{array}{l}\text { Total Yeast } \\
\text { CSA }\left(\mu \mathrm{m}^{2}\right)\end{array}$ & $\begin{array}{l}\text { Total Vacuole } \\
\text { CSA }\left(\mu \mathrm{m}^{2}\right)\end{array}$ & $\begin{array}{l}\% \text { CSA Ratio } \\
\text { (Vacuole/Yeast) }\end{array}$ & & \\
\hline \multirow[t]{2}{*}{30} & 17.3 & $37.5 \pm 11.0$ & $39.6 \pm 10.1$ & $-5.8 \%$ & \multirow[t]{2}{*}{$-3.9 \%$} & 9218.4 & 944.3 & 10.2 & 8711.3 & 1072.5 & 12.3 & $-19.7 \%$ & \multirow[t]{2}{*}{$2.0 \%$} \\
\hline & 30.5 & $37.1 \pm 40.4$ & $40.4 \pm 11.0$ & $-8.8 \%$ & & $13,167.5$ & 1096.6 & 8.3 & $11,450.7$ & 661.9 & 5.8 & $30.7 \%$ & \\
\hline \multirow[b]{2}{*}{35} & 6.5 & $42.6 \pm 12.7$ & $41.4 \pm 12.0$ & $2.7 \%$ & \multirow[b]{2}{*}{$-2.2 \%$} & $13,999.1$ & 3158.3 & 22.6 & $13,304.5$ & 2766.4 & 20.9 & $7.3 \%$ & \multirow[b]{2}{*}{$1.2 \%$} \\
\hline & 19.0 & $42.8 \pm 12.0$ & $44.7 \pm 11.5$ & $-4.4 \%$ & & $15,583.6$ & 2746.6 & 17.6 & $12,862.5$ & 1828.6 & 15.6 & $17.2 \%$ & \\
\hline
\end{tabular}




\subsection{Changes in Morphological State over Fermentation}

At $30{ }^{\circ} \mathrm{C}$, there was a significant difference $(p<0.05)$ between the initial and the final yeast CSA at 30 , whilst at $35^{\circ} \mathrm{C}$, there was not a significant difference $(p>0.05)$ between the initial and the final yeast CSA. Results regarding the CSA ratio between vacuole and yeast CSA showed a significant difference $(p<0.05)$ at $30^{\circ} \mathrm{C}$ but not at $35^{\circ} \mathrm{C}$. Table 3 shows the average of the results obtained from the morphological analysis of yeast at each temperature.

Table 3. Average and standard deviation of yeast CSA and Ratio (vacuole to yeast area) summary *.

\begin{tabular}{cccc}
\hline Temp $\left({ }^{\circ} \mathbf{C}\right)$ & Time $(\mathbf{h})$ & $\begin{array}{c}\text { Average Yeast CSA } \\
\left(\boldsymbol{\mu m}^{\mathbf{2}}\right)\end{array}$ & $\begin{array}{c}\text { \% CSA Ratio } \\
\text { (Vacuole/Yeast) }\end{array}$ \\
\hline & 6.5 & $42.1 \pm 11.2 \mathrm{a}$ & $22.1 \pm 6.5 \mathrm{a}$ \\
30 & 12.5 & $42.4 \pm 10.5 \mathrm{a}$ & $16.3 \pm 2.5 \mathrm{~b}$ \\
& 17.3 & $39.6 \pm 10.1 \mathrm{a}$ & $12.3 \pm 2.2 \mathrm{bc}$ \\
& 20.8 & $38.7 \pm 9.8 \mathrm{a}$ & $918 \pm 4.7 \mathrm{~cd}$ \\
& 30.5 & $40.4 \pm 11.0 \mathrm{a}$ & $5.8 \pm 2.2 \mathrm{~d}$ \\
48.8 & $34.7 \pm 9.5 \mathrm{~b}$ & $3.8 \pm 2.0 \mathrm{~d}$ \\
\hline \multirow{3}{*}{35} & 0.0 & $41.7 \pm 12.4 \mathrm{abc}$ & $13.9 \pm 4.9 \mathrm{~b}$ \\
& 6.5 & $41.4 \pm 12.0 \mathrm{bc}$ & $20.9 \pm 3.7 \mathrm{a}$ \\
& 10.5 & $44.7 \pm 12.7 \mathrm{a}$ & $18.6 \pm 2.8 \mathrm{ab}$ \\
& 14.5 & $44.7 \pm 11.3 \mathrm{a}$ & $15.6 \pm 4.0 \mathrm{~b}$ \\
& 25.0 & $42.0 \pm 12.0 \mathrm{abc}$ & $14.6 \pm 4.2 \mathrm{~b}$ \\
& 31.3 & $38.8 \pm 13.6 \mathrm{c}$ & $14.1 \pm 3.0 \mathrm{ab}$ \\
\hline
\end{tabular}

* The letters presented next to the standard deviation at each temperature were obtained through grouping averages based on Tukey's analysis. Different letters among each column represent significant difference.

The trend of yeast CSA for both temperatures did not show a significant change in size until the end of the fermentation (Figure 7). However, yeast at $35^{\circ} \mathrm{C}$ had on average larger CSAs compared to yeast at $30^{\circ} \mathrm{C}$. These results are consistent with the finding of Gervais et al. [25] who found similar results of an increased cellular volume with increased temperature. They proposed that the increase of the cellular volume is due to a cellular response of yeast to heat shock.

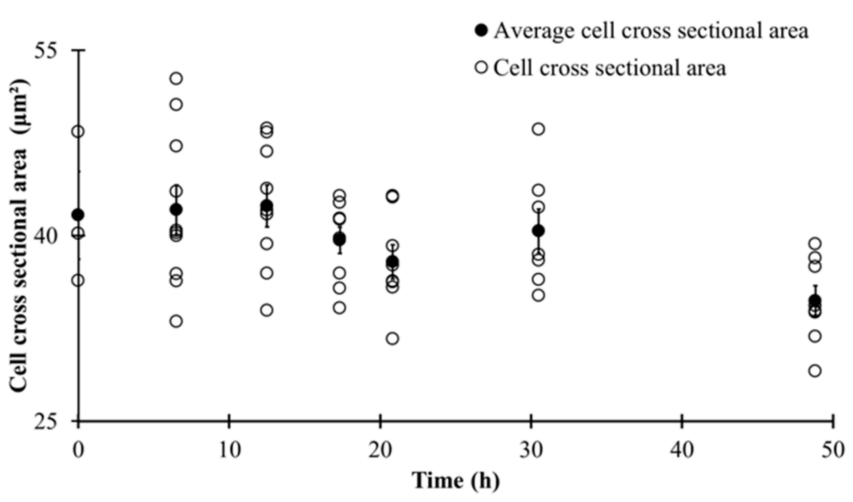

(a)

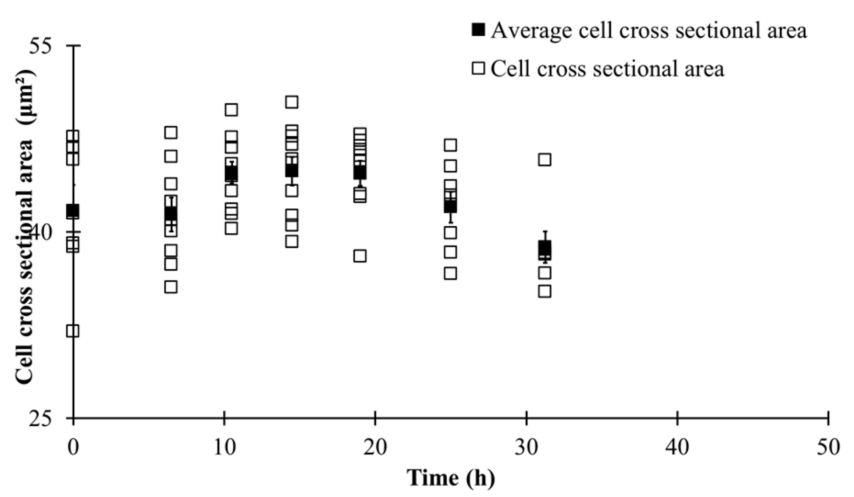

(b)

Figure 7. (a) Yeast CSA with respect to time at $30{ }^{\circ} \mathrm{C}$; (b) Yeast CSA with respect to time at $35{ }^{\circ} \mathrm{C}$. Cross-sectional data are represented as follows: data at $30{ }^{\circ} \mathrm{C}$ (empty circles) and $35^{\circ} \mathrm{C}$ (empty squares); average data at $30{ }^{\circ} \mathrm{C}$ (filled circles) and 35 ${ }^{\circ} \mathrm{C}$ (filled squares). Fermentations and automated image analysis were performed in duplicate. The error bars correspond to the standard error of the data, used to represent the high confidence in the mean associated with a large number of samples.

The ratio between the total CSA of the vacuoles and the total CSA of the cell (Figure 8) had a decreasing trend for $30^{\circ} \mathrm{C}$, but not for $35^{\circ} \mathrm{C}$ (Table 3). This indicates that the vacuolar 
space within the yeast cells was temperature-dependent. The changes undergone by the yeast show morphological changes (vacuole size) that were reported by Pratt et al. [6,7] and Izawa et al. [8]. However, the trends did not match exactly what was described in these studies. This is likely influenced by the highly stressful nature of rum fermentations. By quantifying the differences in yeast morphological state, it becomes possible to determine the impact of stress factors, and the quality of yeast for subsequent fermentations.

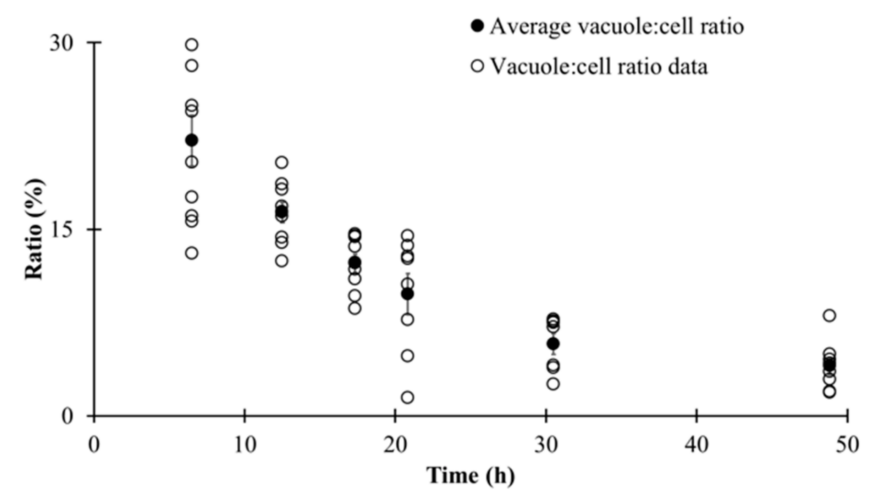

(a)

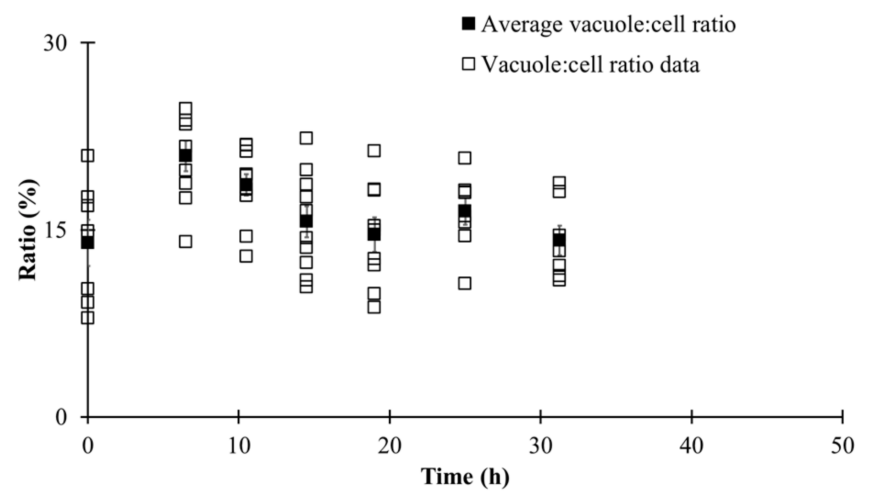

(b)

Figure 8. Vacuole and yeast CSA ratio with respect time at $30{ }^{\circ} \mathrm{C}(\mathbf{a})$ and $35^{\circ} \mathrm{C}(\mathbf{b})$. Ratio data are represented as follows: data at $30{ }^{\circ} \mathrm{C}$ (empty circles) and $35{ }^{\circ} \mathrm{C}$ (empty squares); average data at $30^{\circ} \mathrm{C}$ (filled circles) and $35{ }^{\circ} \mathrm{C}$ (filled squares). Fermentations and automated image analysis were performed in duplicate. The error bars represent the standard error of the data (used to represent the high confidence in the mean associated with a large number of samples).

The change in the yeast CSA, as well as the ratio between the size of vacuoles and the cell throughout the fermentation process, was obtained using an automated yeast analysis. Figures 7 and 8 clearly indicate that yeast has the capacity to undergo large morphological changes over a single fermentation, as has been observed by many researchers. Therefore, characterizing the rate of fermentation with respect to temperature, based upon the rate of sugar consumption per cell, is an incomplete assessment and it could lead to incorrect conclusions. A more detailed analysis was possible through the combination of the yeast CSAs obtained from the automated tool developed in this study, and the enumeration of viable yeast cells within suspension. Using the modeled number of cells in suspension and combining with the average surface area of yeast within suspension (estimated based on the assumption of yeast spherical shape), the total surface area of yeast in suspension over time was determined, as shown in Figure 9. This analysis has implications for reactions that are dependent upon cell wall area, such as nutrient uptake and stress responses.

Building upon this analysis, it became apparent that the rate of fermentation per cell changed over the duration of the fermentation and was dependent upon temperature. There are many factors that influence the rate of fermentation per cell, including temperature, sugar concentrations within the media, stress levels, etc. However, one parameter that could be accounted for was the total volume of yeast cells present. To determine the sugar consumption rate per volume of yeast, the authors used the CSA to determine the average volume of cells at each time period (assuming spherical cells). As the vacuole volume is not expected to be involved in cellular metabolism (and makes up a significant portion of the volume in early fermentation cells (Figure 8)), the vacuolar volume was subtracted from the average yeast volume calculation, resulting in an estimate of non-vacuolar cell volume. This value was multiplied by the model of cells in suspension to find the non-vacuolar cell volume per milliliter. Finally, the rate of sugar consumption model was divided by this value to find the sugar consumption rate per non-vacuolar cell volume; it is presented in Figure 10. This analysis shows that the sugar consumption rate per total non-vacuolar yeast volume declined with respect to time (and sugar concentration), and was higher at $35^{\circ} \mathrm{C}$. This analysis has applications for optimizing the reaction rate for fixed-bed, 
encapsulated yeast and other fermentations where there is not expected to be new yeast growth. It can also help predict nutrient requirements and properties of yeast populations produced under different temperature profiles for alternative fermentation processes such as chemostats reactors.

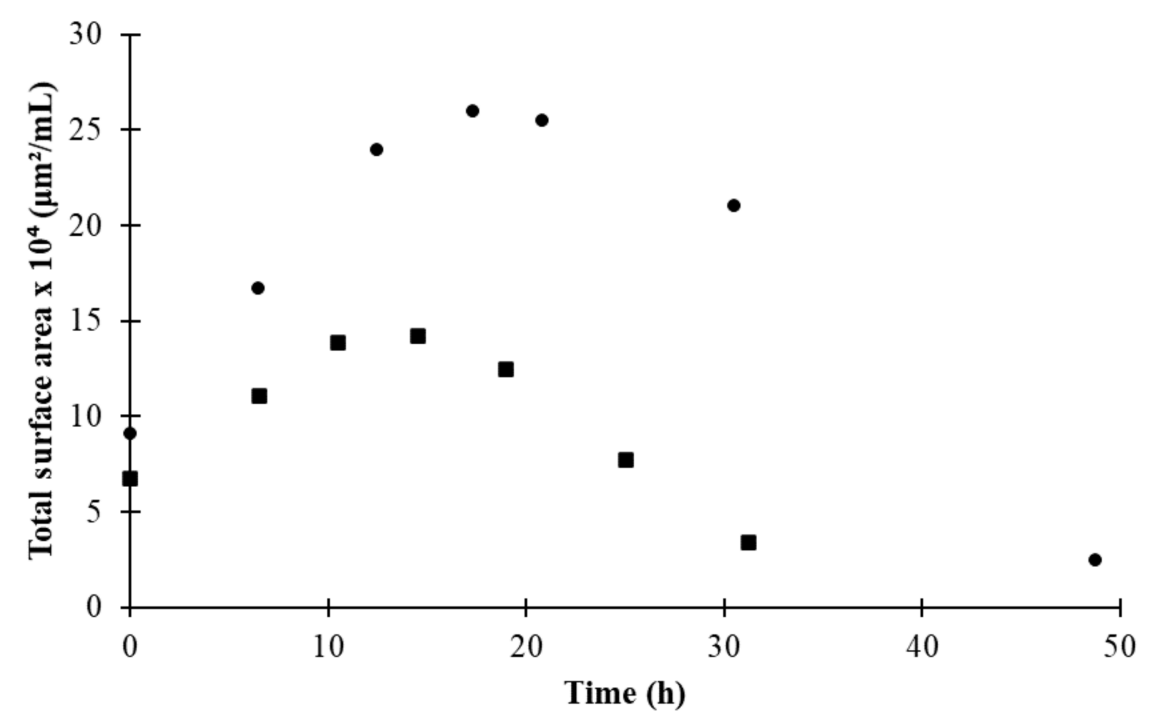

Figure 9. Total surface area of yeast in suspension per milliliter with respect to fermentation time. Data are presented as follows: average total surface area of suspended yeast per milliliter at $30{ }^{\circ} \mathrm{C}$ (circles) and $35^{\circ} \mathrm{C}$ (squares).

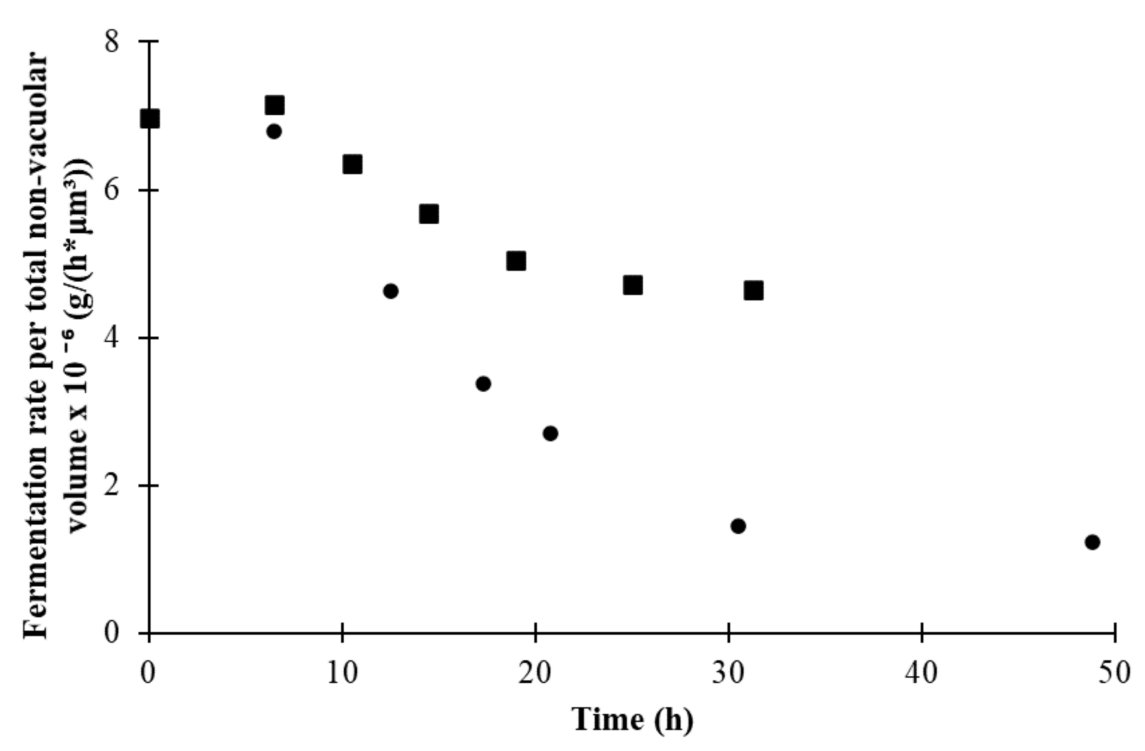

Figure 10. Fermentation rate per total non-vacuolar volume over time. Data are presented as follows: fermentation rate per total non-vacuolar volume at $30^{\circ} \mathrm{C}$ (circles) and $35^{\circ} \mathrm{C}$ (squares).

\section{Conclusions}

Fermentations were conducted in duplicate at two different temperatures resulting in differences in yeast morphology and fermentation kinetics between the experiments. Standard methods were used to evaluate the fermentation properties, while changes to morphology were assessed using manual and automated image analysis. Differences in fermentation rate, number of cells in suspension, and cell size found were consistent with previous work. An average discrepancy of only $2-4 \%$ was found between the manual and automated analysis of the images. There were high standard deviations for cellular morphology measurements (due to natural variability present within the yeast population), 
however, through the automated analysis of hundreds of cells, clear trends were observed. From the automated image analysis, changes to yeast CSA appeared to be temperaturedependent and progressed throughout the fermentation. Decreases in CSA ratio, defined as the ratio between the vacuole and yeast CSA, were observed at $30^{\circ} \mathrm{C}$ and not at $35^{\circ} \mathrm{C}$. There were very small, or no vacuoles present in the cells at the end of the fermentation at $30^{\circ} \mathrm{C}$. Finally, the automated image analysis of cell morphology was combined with traditional measurements to provide insight into cellular surface areas and sugar consumption rates. The rate of fermentation per total non-vacuolar yeast volume decreased over the course of the fermentation and was higher at $35^{\circ} \mathrm{C}$ despite a lower total rate of fermentation. This study showed that automated analysis of images can be used to track morphological changes in yeast over a fermentation, and that the combination of this analysis with traditional methods can be used to provide additional insight into yeast properties and behavior.

Author Contributions: Conceptualization, A.J.M. and M.G.-D.; methodology, M.G.-D.; software, M.C.; validation, M.G.-D., M.C.; formal analysis, A.J.M., M.G.-D.; investigation, M.G.-D.; resources, A.J.M.; data curation, M.G.-D., M.C.; writing-original draft preparation, A.J.M., M.G.-D., M.C.; writing-review and editing, K.A.T.-W.; visualization, M.G.-D., K.A.T.-W.; supervision, A.J.M.; project administration, A.J.M.; funding acquisition, A.J.M. All authors have read and agreed to the published version of the manuscript.

Funding: This research received no external funding.

Institutional Review Board Statement: Not applicable.

Informed Consent Statement: Not applicable.

Data Availability Statement: Most of the data presented in this study is available within the article itself. The (large) collection of raw image files are available upon request from the corresponding author.

Acknowledgments: The authors would like to acknowledge Lallemand Inc. for the donation of yeast used throughout this research, the Food Science and Human Nutrition department at the University of Florida for use of the facilities, and Victor Cedeño for the technical support involving microscope and software.

Conflicts of Interest: The authors declare no conflict of interest.

\section{References}

1. Wunderlich, S.; Back, W. 1-Overview of Manufacturing Beer: Ingredients, Processes, and Quality Criteria. In Beer in Health and Disease Prevention; Elsevier B.V.: Burlington, MA, USA, 2009; pp. 3-16. [CrossRef]

2. Tibayrenc, P.; Preziosi-Belloya, L.; Roger, J.M.; Ghommidha, C. Assessing yeast viability from cell size measurements? J. Biotechnol. 2010, 149, 74-80. [CrossRef] [PubMed]

3. Wang, J.; Ding, H.; Zheng, F.; Li, Y.; Liu, C.; Niu, C.; Li, Q. Physiological Changes of Beer Brewer's Yeast during Serial Beer Fermentation. J. Am. Soc. Brew. Chem. 2019, 77, 10-20. [CrossRef]

4. Zakhartsev, M.; Reuss, M. Cell size and morphological properties of yeast Saccharomyces cerevisiae in relation to growth temperature. FEMS Yeast Res. 2018, 18, foy052. [CrossRef] [PubMed]

5. Coelho, M.; Belo, I.; Pinheiro, R.; Amaral, A.; Mota, M.; Coutinho, J.; Ferreira, E. Effect of hyperbaric stress on yeast morphology: Study by automated image analysis. Appl. Microbiol. Biotechnol. 2004, 66, 318-324. [CrossRef] [PubMed]

6. Pratt, P.; Bryce, J.; Stewart, G. The Effects of Osmotic Pressure and Ethanol on Yeast Viability and Morphology. J. Inst. Brew. 2003, 109, 218-228. [CrossRef]

7. Pratt, P.; Bryce, J.; Stewart, G. The Yeast Vacuole-A Scanning Electron Microscopy Study during High Gravity Wort Fermentations. J. Inst. Brew. 2007, 113, 50-60. [CrossRef]

8. Izawa, S.; Ikeda, K.; Miki, T.; Wakai, Y.; Inoue, Y. Vacuolar morphology of Saccharomyces cerevisiae during the process of wine making and Japanese sake brewing. Appl. Microbiol. Biotechnol. 2010, 88, 277-282. [CrossRef] [PubMed]

9. Kida, K.; Gent, D.; Slaughter, J.C. Effect of vacuoles on viability of Saccharomyces cerevisiae. J. Ferment. Bioeng. 1993, 76, 284-288. [CrossRef]

10. Cahill, G.; Walsh, P.; Donnelly, D. Improved Control of Brewery Yeast Pitching Using Image Analysis. J. Am. Soc. Brew. Chem. 2018, 57, 72-78. [CrossRef]

11. O'Shea, D.; Walsh, P. The effect of culture conditions on the morphology of the dimorphic yeast Kluyveromyces marxianus var. marxianus NRRLy2415: A study incorporating image analysis. Appl. Microbiol. Biotechnol. 2000, 53, 316-322. [CrossRef] [PubMed] 
12. Ginovart, M.; Carbó, R.; Blanco, M.; Portell, X. Digital Image Analysis of Yeast Single Cells Growing in Two Different Oxygen Concentrations to Analyze the Population Growth and to Assist Individual-Based Modeling. Front. Microbiol. 2018, 8, 2628. [CrossRef] [PubMed]

13. Ohtani, M.; Saka, A.; Sano, F.; Ohya, Y.; Morishita, S. Development of image processing program for yeast cell morphology. J. Bioinform. Comput. Biol. 2004, 1, 695-709. [CrossRef] [PubMed]

14. Grishagin, I. Automatic cell counting with ImageJ. Anal. Biochem. 2015, 473, 63-65. [CrossRef] [PubMed]

15. Wilson, C.; Lukowicz, R.; Merchant, S.; Valquier-Flynn, H.; Caballero, J.; Sandoval, J.; Okuom, M.; Huber, C.; Durham Brooks, T.; Wilson, E.; et al. Quantitative and Qualitative Assessment Methods for Biofilm Growth: A Mini-review. Res. Rev. J. Eng. Technol. 2017, 6. Available online: http:/ / www.rroij.com/open-access/quantitative-and-qualitative-assessment-methods-for-biofilmgrowth-a-minireview-.pdf (accessed on 5 March 2021).

16. Stolze, N.; Bader, C.; Henning, C.; Mastin, J.; Holmes, A.; Sutlief, A. Automated image analysis with ImageJ of yeast colony forming units from cannabis flowers I Elsevier Enhanced Reader. J. Microbiol. Methods 2019, 164, 105681. [CrossRef] [PubMed]

17. ASBC. Wort-12: Free Amino Nitrogen. Method, A. Ninhydrin method (international method). In Wort Methods; American Society of Brewing Chemists: St. Paul, MN, USA, 2011.

18. ASBC. Yeast-4: Microscopic yeast cell counting. In Wort Methods; American Society of Brewing Chemists: St. Paul, MN, USA, 2004.

19. Painting, K.; Kirsop, B. A quick method for estimating the percentage of viable cells in a yeast population, using methylene blue staining. World J. Microbiol. Biotechnol. 1990, 6, 346-347. [CrossRef] [PubMed]

20. ASBC. Yeast-14: Miniature fermentation assay. In Wort Methods; American Society of Brewing Chemists: St. Paul, MN, USA, 2011; pp. 1-3.

21. Rudolph, A.; MacIntosh, A.J.; Speers, R.A.; St. Mary, C. Modeling Yeast in Suspension during Laboratory and Commercial Fermentations to Detect Aberrant Fermentation Processes. J. Am. Soc. Brew. Chem. 2020, 78, 63-73. [CrossRef]

22. Ferreira, T.; Rasband, W. ImageJ User Guide IJ 1.46r. 2012. Available online: https://imagej.nih.gov/ij/docs/guide/user-guideA4booklet.pdf (accessed on 5 March 2021).

23. Torija, M.; Rozès, N.; Poblet, M.; Guillamón, J.; Mas, A. Effects of fermentation temperature on the strain population of Saccharomyces cerevisiae. Int. J. Food Microbiol. 2003, 80, 47-53. [CrossRef]

24. Reddy, L.; Reddy, O. Effect of fermentation conditions on yeast growth and volatile composition of wine produced from mango (Mangifer indica L.) fruit juice. Food Bioprod. Process. 2011, 89, 487-491. [CrossRef]

25. Gervais, P.; Martínez de Marañón, I.; Evrard, C.; Ferret, E.; Moundanga, S. Cell volume changes during rapid temperature shifts. J. Biotechnol. 2003, 102, 269-279. [CrossRef] 